\title{
PENGEMBANGAN MODUL PEMBELAJARAN FISIKA BERBASIS PROYEK (PROJECT BASED LEARNING) PADA MATERI FLUIDA STATIS UNTUK MENINGKATKAN KREATIVITAS BELAJAR SISWA KELAS X SMA/MA
}

\author{
Nur Kholis Novianto ${ }^{1}$, Mohammad Masykuri², Sukarmin $^{3}$ \\ ${ }^{1}$ Magister Pendidikan Sains, Fakultas Keguruan dan Ilmu Pendidikan, Universitas Sebelas Maret \\ Surakarta, 57126, Indonesia \\ nurcholisnovianto@student.uns.ac.id \\ ${ }^{2}$ Magister Pendidikan Sains, Fakultas Keguruan dan Ilmu Pendidikan, Universitas Sebelas Maret \\ Surakarta, 57126, Indonesia \\ mmasykuri@staff.uns.ac.id \\ ${ }^{3}$ Magister Pendidikan Sains, Fakultas Keguruan dan Ilmu Pendidikan, Universitas Sebelas Maret \\ Surakarta, 57126, Indonesia \\ sukarmin67@staff.uns.ac.id
}

\begin{abstract}
Abstrak
Pembelajaran menggunakan metode ceramah mengakibatkan kreativitas belajar siswa rendah. Tujuan dari penelitian ini adalah untuk 1) mengetahui karakteristik khusus modul fisika berbasis Project Based Learning (PjBL) pada materi fluida statis untuk kelas X SMA/ MA, 2) mendapatkan modul pembelajaran fisika berbasis proyek (Project Based Learning) yang telah memenuhi kriteria layak, dan 3) mengetahui peningkatan kreativitas belajar siswa setelah menggunakan modul fisika berbasis proyek (Project Based Learning) pada materi fluida statis. Jenis penelitian ini adalah penelitian dan pengembangan (Research and Development) yang mengadaptasi model 4-D dari Thiagarajan, dkk (1974) yang meliputi tahap define, design, develop dan disseminate. Instrumen yang digunakan adalah angket, lembar observasi dan tes. Uji lapangan operasional menggunakan one group pretest-posttest design. Analisis data yang digunakan dalam penelitian dalam tahap define adalah analisis deskriptif, pada tahap design menggunakan analisis $\mathrm{KD}$, tahap develope menggunakan analisis kuantitatif deskriptif dengan cara mengkonversi data menjadi kategori skala 4 untuk hasil validasi modul, hasil penilaian sikap dan hasil penilaian keterampilan sedangkan penilaian kreativitas belajar dianalisis menggunakan $n$-gain ternormalisasi. Tahap disseminate menggunakan analisis deskriptif dari hasil penilaian modul dalam kategori skala 4. Berdasarkan analisis data diperoleh hasil penelitian dan pengembangan sebagai berikut: 1) karakter khusus modul pembelajaran berbasis PjBL memiliki enam sintaks pembelajaran yang diintegrasikan di dalam rubrik modul dengan perincian ; (a) sintaks penentuan pertanyaan mendasar diintegrasikan dalam rubrik 'Ayo Mencari Tahu!', (b) sintaks perancangan proyek diintegrasikan dalam rubrik 'Ayo Mendesain Proyek!', (c) sintaks penyusunan jadwal pembuatan proyek diintegrasikan dalam rubrik 'Mari Menyusun Jadwal!', (d) sintaks pengawasan kemajuan proyek diintegrasikan dalam rubrik 'Saatnya Memonitor!', (e) sintaks pengujian hasil diintegrasikan dalam rubrik 'Waktunya Menguji Hasil!', dan (f) sintaks pengevaluasian pengalaman yang diintegrasikan ke dalam rubrik 'Ayo Berbagi Pengalaman!', 2) modul fisika berbasis PjBL yang dikembangkan memenuhi kriteria layak pada aspek kelayakan isi dan penyajian, kelayakan bahasa, kelayakan aspek pembelajaran $\mathrm{PjBL}$, dan kelayakan kegrafikan dengan nilai rata-rata 3,8 atau dalam kategori 'sangat baik', 3) pembelajaran menggunakan modul pembelajaran fisika berbasis $\mathrm{PjBL}$ pada materi fluida statis dapat meningkatkan kreativitas belajar siswa dengan nilai gain 0,46 atau dalam kategori sedang.
\end{abstract}

Kata Kunci : Modul, Project Based Learning (PjBL), Kreativitas Belajar.

\section{Pendahuluan}

Proses pendidikan di indonesia belum berjalan begitu baik sehingga masih digolongkan memiliki kualitas pendidikan yang rendah. Kualitas pendidikan yang rendah mempengaruhi Indeks Pembangunan Manusia (IPM) suatu Negara. Berdasarkan data yang 
dikeluarkan oleh The United Nations Development Programs (UNDP) tahun 2011, Indeks Pembangunan Manusia (IPM ) atau Human Development Index (HDI) Indonesia mengalami penurunan dari peringkat 108 pada 2010 menjadi peringkat 124 pada tahun 2012 dari 180 negara, dan pada 14 Maret 2013 dilaporkan naik tiga peringkat menjadi urutan ke-121 dari 185 negara, sedangkan Juli 2014 Indonesia berada pada peringkat 108 dari 187 negara. Laporan lain dirilis oleh OECD (Organization for Economic Cooperation and Development) pada majalah BBC dan Financial Times 13 mei 2015, yang menempatkan pendidikan Indonesia dalam peringkat 69 dari 76 negara. Laporan yang diluncurkan oleh OECD ini memperlihatkan bahwa standar pendidikan adalah sesuatu yang penting dan merupakan alat prediksi bagi kesejahteraan jangka panjang suatu Negara. Berdasarkan data diatas maka sangatlah perlu untuk memperbaiki kualitas pembelajaran di Indonesia demi kesejahteraan masyarakat Indonesia yang lebih baik.

Salah satu fokus perbaikan pendidikan di Indonesia adalah perbaikan kreativitas belajar siswa. Kreativitas telah menjadi bagian penting dalam wacana peningkatan mutu pembelajaran, hingga kini kreativitas telah diterima baik sebagai kompetensi yang melekat pada proses dan hasil belajar. Inti kreativitas adalah menghasilkan sesuatu yang lebih baik atau sesuatu yang baru (De Graff \& Lawrence, 2002). Baru bisa bermakna sebagai hasil menyempurnakan, menambahkan, mengubah, dan mereposisi dari sesuatu yang ada sebelumnya sehingga sesuatu berubah menjadi lebih baik. Apabila guru menggunakan konsep tersebut sebagai dasar pengembangan pembelajaran, maka kualitas sumber daya manusianya pasti semakin baik. Pendapat De Graff \& Lawrence itu diperkuat oleh hasil penelitian Mukayatun et al (2013) dan Novitayani (2015: 98) mengenai pentingnya kreativitas dalam pembelajaran bahwa, kreativitas yang tinggi mempengaruhi suasana dan hasil belajar siswa. Sehingga kreativitas dipandang sangat perlu ditingkatkan dalam sebuah proses pembelajaran demi tercapainya kualitas pembelajaran yang lebih baik.

Salah satu upaya mengembangkan kreativitas belajar adalah dengan model pembelajaran berbasis proyek (Project Based Learning (PjBL)). Basis pendidikan yang menekankan pada proyek menurut Sampurno (2009) dapat memaksimalkan aktivitas siswa dalam pembelajaran, dapat meningkatkan kreativitas, kemampuan berpikir kritis dan kinerja ilmiah siswa dan membantu para siswa untuk mengembangkan keterampilan belajar jangka panjang. Pembelajaran berbasis proyek memiliki potensi yang amat besar untuk membuat pengalaman belajar yang lebih menarik dan bermakna untuk siswa serta dapat meningkatkan kinerja ilmiah siswa dalam pembelajaran, sedangkan guru hanya berperan sebagai fasilitator dan mediator. Studi kasus yang dilakukan oleh Grant \& Tamim (2013: 5) juga menyimpulkan bahwa $\mathrm{PjBL}$ dapat mendukung, memfasilitasi, dan meningkatkan kualitas dan proses pembelajaran, dan sekaligus juga dapat memperkaya kreativitas belajar siswa. Keuntungan - keuntungan pembelajaran berbasis proyek yang lain menurut hasil investigasi Yalcin et al (2009: 2) yaitu dapat (1) menciptakan suasana belajar yang bervariasi, (2) menghindarkan dari atmosfer kebosanan yang biasa di dapat di sekolah, dan (3) membuat lingkungan belajar lebih menarik, menyenangkan, menggairahkan, dan membanggakan bagi siswa. Berdasarkan alasan tersebut maka pembelajaran berbasis proyek perlu untuk diterapkan dalam proses pembelajaran.

Dalam proses pembelajaran diperlukan bahan ajar dalam bentuk modul agar peserta didik dapat belajar secara mandiri. Selain itu, modul juga dapat berfungsi sebagai bahan rujukan dan alat evaluasi untuk peserta didik. Pendapat senada juga diutarakan oleh Kiong et al (2011: 1) dalam penelitiannya yang menyebutkan bahwa dengan menggunakan modul dapat menjadi alternatif pendekatan siswa dalam pemecahan permasalahan belajar siswa. Selain hal tersebut, Novitayani (2015: 97) juga menyimpulkan dalam penelitiannya bahwa penggunaan modul dapat membantu proses pembelajaran dalam meningkatkan 
kreativitas belajar siswa. Oleh karena itu, pengemasan modul yang baik dan sesuai perlu disusun agar dapat memfasilitasi siswa dalam mencapai pembelajaran yang baik.

Materi yang dibahas dalam modul ini adalah materi fluida statis. Pemilihan materi ini berdasarkan hasil analisis evaluasi hasil belajar pada Ujian Nasional Tahun 2013/ 2014 yang mengkategorikan materi fluida termasuk materi yang sulit dipahami dengan persentase penguasaan $46 \%$ di kabupaten Karanganyar. Materi ini memerlukan penemuan konsep, pemahaman, dan aplikasi yang nyata dalam kehidupan sehari-hari. Fluida statis menjadi materi yang sulit untuk dipahami karena penyampaian materi ini belum banyak dilakukan dengan cara langsung dan kontekstual seperti membuat proyek. Padahal, sesuai dengan kerucut pengalaman Edgar Dale dalam Susilana \& Riyana (2007: 7) yang menyatakan bahwa belajar dengan pengalaman langsung atau kontekstual merupakan tingkatan belajar yang paling konkrit, karena siswa dihadapkan langsung dengan lingkungan sekitarnya. Oleh karena itu, semua materi harus dapat disampaikan dengan metode dan bahan ajar yang sesuai dengan isi materinya agar siswa dapat dengan mudah menerima materi tersebut. Isi materi dalam fluida statis sangat cocok disampaikan dengan pembelajaran berbasis $\mathrm{PjBL}$.

Berdasarkan studi pendahuluan yang dilakukan di SMAN 2 Karanganyar melalui analisis kebutuhan siswa didapatkan data bahwa hanya $20 \%$ siswa yang memiliki sumber belajar (buku teks) selain yang diberikan oleh sekolahnya. sebanyak $80 \%$ siswa mengaku mengalami kesulitan belajar karena keterbatasan sumber belajarnya. Maka dari itu diperlukan solusi alternatif untuk mengatasi masalah belajar anak-anak tersebut, salah satunya melalui pembuatan modul. Dalam analisis tersebut juga didapatkan data bahwa $90 \%$ peserta didik menyatakan butuh bahan ajar yang juga dapat membantu kreativitasnya misalnya modul berbasis $\mathrm{PjBL}$ dan $80 \%$ peserta didik setuju apabila dikembangkan modul pembelajaran fisika yang berbasis PjBL. Data hasil analisis kebutuhan guru menyebutkan bahwa memang
50\% lebih siswa mengalami kesulitan belajar. Guru juga masih mengalami kesulitan dalam mengembangkan perangkat pembelajaran yang efektif, inovatif, kreatif dan efektif dan menyenangkan dalam mengimplementasikan pendidikan di kurikulum 2013 yang ideal. Maka dari itulah perlunya kesinambungan akan pentingnya kerjasama antar semua elemen masyarakat dalam bidang pendidikan, agar terselanggaranya pendidikan yang berkualitas dan maju.

\section{Metode Penelitian}

Metode penelitian yang digunakan yaitu research and development atau penelitian dan pengembangan. Metode penelitian dan pengembangan adalah metode penelitian yang digunakan untuk menghasilkan produk tertentu (Sugiyono, 2012). Model yang digunakan sebagai dasar untuk mengembangkan modul fisika berbasis $\mathrm{PjBL}$ ini merupakan hasil adapatasi model 4-D (four-D model) yang dkemukakan oleh Thiagarajan, dkk (1974: 5) yang meliputi proses define, design, develop, dan disseminate.

Desain penelitian yang digunakan adalah one group pretest and posttest, sehingga penelitian hanya melibatkan sekelompok subjek yang diberi pre-test sebelum dikenai perlakuan, dan post-test setelah dikenai perlakuan untuk diketahui hasil akibat perlakuan tersebut.

Metode pengumpulan data yang digunakan pada penelitian ini yaitu dengan teknik tes, angket dan observasi. Teknik tes yang digunakan diperuntukkan untuk meniai aspek pengetahuan siswa dan berbentuk tes essay. Teknik angket dipergunakan dalam pengukuran peningkatan kreativitas belajar siswa dengan instrumen yang sudah diujicobakan dan dinyatakan valid dan reliable. Teknik observasi digunakan dalam pengukuran aspek sikap belajar, aspek keterampilan, analisis kebutuhan, dan penilaian produk yang seluruh instrumennya sudah divalidasi oleh pembimbing.

Data yang diperoleh pada penelitian pengembangan modul berbasis $\mathrm{PjBL}$ pada materi fluida statis untuk siswa SMA/MA 
kelas $\mathrm{X}$ adalah data analisis kebutuhan siswa, data analisis kebutuhan guru, data analisis bahan ajar, data validasi modul oleh validator ahli (materi, bahasa dan kegrafikan), guru fisika dan teman sejawat, data nilai sikap, pengetahuan dan keterampilan, data nilai peningkatan kreativitas belajar siswa, dan data penilaian produk oleh siswa, guru fisika, dan teman sejawat. Data yang diperoleh dari analisis kebutuhan siswa, analisis kebutuhan guru, dan analisis bahan ajar kemudian ditabulasi dan dikonversi menjadi bentuk persentase. Hasil validasi modul, nilai sikap, nilai keterampilan dan hasil penilaian produk dianalisis dan dikonversi menjadi skala 4 kemudian dilakukan analisis deskriptif terhadap hasilnya. Hasil penilaian pengetahuan dianalisis dengan membuat rata-rata nilai kemudian dibandingkan dengan kriteria ketuntasan minimal mata pelajaran fisika, sedangkan hasil pretest dan posttest dari angket kreativitas belajar siswa dianalisis dan ditentukan peningkatannya dengan n-gain ternormalisasi (Meltzer, 2001). Kreativitas belajar siswa dikatakan meningkat ketika hasil perhitungan gain minimal memiliki kategori sedang.

\section{Hasil dan Pembahasan Penelitian}

Model yang digunakan sebagai dasar untuk mengembangkan modul fisika berbasis PjBL ini merupakan hasil adapatasi model 4-D (four-D model) yang dkemukakan oleh Thiagarajan, dkk (1974: 5) dalam yang meliputi proses define, design, develop, dan disseminate yang menunjukkan hasil sebagai berikut :

\section{Tahap Define}

Tahap ini merupakan tahapan untuk mengidentifikasi masalah-masalah yang ada dalam proses pembelajaran dan menjadi dasar untuk merancang produk berupa modul yang dibuat. Pada tahapan ini dilakukan analisis kebutuhan siswa, analisis kebutuhan guru, analisis bahan ajar dan analsis materi pembelajaran.

Analisis kebutuhan siswa dilakukan terhadap 10 siswa yang berasal dari kelas X-
MIPA SMAN 2 Karanganyar. Data yang dihasilkan antara lain memperlihatkan bahwa kepemilikan bahan dan sumber belajar anak sangat rendah yakni hanya $20 \%$. Hal tersebut membuat siswa mengalami kesulitan dalam belajar, padahal menurut Haryanto (2013: 23) menyebutkan bahwa pemanfaatan sumber belajar berupa media pembelajaran penting agar membuat komunikasi dalam kegiatan belajar semakin efektif dan efisien. Atas dasar tersebut maka besar kemungkinan pengembangan modul pembelajaran dapat mengatasi permasalahan tersebut. Hal ini diperkuat oleh hasil penelitian Kiong et al (2011) bahwa penggunaan modul dapat menjadi alternatif dalam pemecahan masalah belajar siswa.

Analisis kebutuhan guru dilakukan menggunakan bantuan angket kebutuhan guru dan dilakukan terhadap 4 guru fisika di SMAN 2 Karanganyar. Hasil analisis antara lain menunjukkan bahwa usaha peningkatan aspek kreativitas dalam pembelajaran masih rendah yakni sebesar $56 \%$ dan pengoptimalan penggunaan laboratorium dan perpustakaan juga masih rendah (38\%). Atas pertimbangan analisis kebutuhan guru tersebut, peneliti mengembangkan modul pembelajaran fisika berbasis $\mathrm{PjBL}$ dalam usaha meningkatkan kualitas pembelajaran. Pertimbangan tersebut dikuatkan oleh hasil penelitian Grant \& Tamim (2013) yang menyebutkan bahwa penggunaan PjBL dalam pembelajaran dapat mendukung, memfasilitasi, dan meningkatkan kualitas dan proses pembelajaran, dan juga dapat memperkaya kreativitas belajar siswa.

Hasil analisis bahan ajar cetak yang dipakai di SMAN 2 Karanganyar kelas XMIPA menunjukkan kurangnya pemenuhan komponen pembelajaran berbasis PjBL. Bahan ajar yang dianalisis adalah bahan ajar sesuai kurikulum 2013 yang peneliti kumpulkan dari guru dan siswa yang terdiri dari 3 jenis buku yang berbeda penerbit. Hasil analisis memperlihatkan bahwa kategori aspek pembelajaran $\mathrm{PjBL}$ yang dinilai dari buku tersebut rata-rata masih berkategori rendah dengan skor rata-rata 2,17. Berdasarkan data analisis tersebut maka layak jika peneliti 
mengembangkan modul berbasis PjBL dalam pembelajaran fisika.

Materi yang dipilih dalam penelitian ini adalah materi fluida statis. Hal ini berdasarkan hasil daya serap penguasaan materi soal ujian nasional SMA/MA yang dikeluarkan oleh Balai Penilaian Pendidikan Badan Penelitian dan Pengembangan Kementrian Pendidikan dan Kebudayaan yang tergolong masih rendah di SMAN 2 Karanganyar (46,28\%) dan perlu adanya perbaikan. Berdasarkan Permendikbud RI no.59 Tahun 2014 tentang kurikulum 2013, pada Lampiran 3 PMP Fisika Minat SMA (2014: 928) tentang pilihan model pembelajaran yang sesuai dengan karakteristik kompetensi mata pelajaran fisika menyebutkan bahwa kompetensi dasar menerapkan hukumhukum pada fluida statis dalam kehidupan sehari-hari pada kelas X-MIPA sangat cocok diterapkan dengan pembelajaran berbasis PjBL. Atas pertimbangan tersebut, layak jika peneliti mengembangkan modul pembelajaran berbasis PjBL pada materi fluida statis.

\section{Tahap Design}

Dalam tahap design ini peneliti membuat desain modul sesuai dengan sintaks PjBL yang telah diintegrasikan ke dalam komponen modul. Sintaks penentuan pertanyaan mendasar diintegrasikan ke dalam rubrik 'Ayo Mencari Tahu!', sintaks perancangan proyek diintegrasikan ke dalam rubrik 'Ayo Mendesain Proyek!', sintaks penyusunan jadwal diintegrasikan ke dalam rubrik 'Mari Menyusun Jadwal!', sintaks pengawasan kemajuan proyek diintegrasikan ke dalam rubrik 'Saatnya Memonitor!', sintaks pengujian hasil diintegrasikan ke dalam rubrik 'Waktunya Menguji Hasil!', dan sintaks pengevaluasian pengalaman diintegrasikan ke dalam rubrik 'Ayo Berbagi Pengalaman!'.

Seluruh desain pembelajaran PjBL yang disusun diatas kemudian dikemas ke dalam empat kegiatan belajar (KB) dan dilengkapi dengan alat evaluasi, rubrik 'sekilas fisika', rangkuman materi, daftar pustaka, glosarium dan jawaban soal evaluasi. Desain modul yang sudah jadi selanjutnya menjadi draft I modul pembelajaran fisika berbasis Project Based Learning (PjBL) pada materi fluida statis.
Modul yang sudah jadi kemudian di validasi dan di revisi sesuai dalam tahap pengembangan (develop) dalam proses penelitian selanjutnya.

\section{Tahap Develop}

Tahapan Develop ini diawali dengan validasi draft 1 modul fisika berbasis $\mathrm{PjBL}$ yang dilakukan oleh validator ahli, guru fisika dan teman sejawat yang selanjutnya direvisi dan ujicobakan ke kelompok kecil dan kelompok besar.

\section{Hasil Validasi Modul}

Validasi dilakukan oleh dua validator ahli, dua guru fisika dan dua teman sejawat. Validasi dilakukan menggunakan lembar validasi yang mengadaptasi lembar validasi buku teks pelajaran dari BSNP tahun 2014. Validasi modul menitikberatkan pada komponen kelayakan isi dan penyajian, bahasa, pembelajaran berbasis $\mathrm{PjBL}$, dan kelayakan kegrafisan. Dua validator ahli memvalidasi modul yang telah dibuat dengan menilai komponen penyajian materi yang terdiri dari komponen kelayakan isi, komponen penyajian, komponen kebahasaan, dan komponen pembelajaran berbasis PjBL, sedangkan komponen yang dinilai dari segi media dalam modul adalah komponen kegrafikan. Dua guru fisika dan dua teman sejawat juga menilai komponen materi yang terdiri dari komponen kelayakan isi, komponen penyajian, komponen kebahasaan dan komponen pembelajaran PjBL. Terdapat juga validator ahli media yang menilai tentang kelayakan kegrafikan modul dan ahli bahasa yang menilai tentang kebahasaan di dalam modul.

Diagram batang hasil validasi modul pembelajaran berbasis Project Based Learning (PjBL) yang dikembangkan peneliti diperlihatkan dalam Gambar 1. 


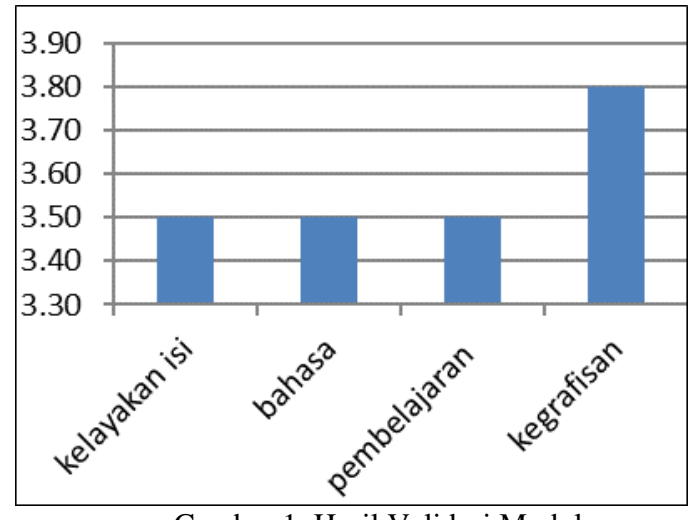

Gambar 1. Hasil Validasi Modul

Hasil validasi yang ditunjukkan Gambar 1 memperlihatkan bahwa modul pembelajaran berbasis $\mathrm{PjBL}$ yang dikembangkan oleh peneliti mendapatkan nilai rata-rata 3,5 pada penilaian kelayakan isi, bahasa dan penyajian dan 3,8 pada komponen kegrafikan, sehingga secara keseluruhan mendapatkan nilai rata-rata 3,6 atau dalam kategori 'sangat baik'. Nilai ini berarti bahwa modul yang dikembangkan sangat baik dari segi isi dan penyajian, kebahasaan, penyajian pembelajaran $\mathrm{PjBL}$ dan kegrafikan sehingga sangat layak digunakan dalam pembelajaran.

\section{Revisi I}

Setelah validasi dilakukan, draf I kemudian direvisi berdasarkan saran/ masukan dari validator seperti ditampilkan dalam Tabel 1.

Tabel. 1 Hasil Revisi Modul dari Validator

\begin{tabular}{|c|c|}
\hline Sebelum revisi & Setelah revisi \\
\hline $\begin{array}{l}\text { Peta konsep harus ada } \\
\text { hubungan silang dan pada } \\
\text { kolom bukan konsep tidak di } \\
\text { beri objek }\end{array}$ & $\begin{array}{l}\text { Sudah diperbaiki dengan } \\
\text { menghapus kotakan pada } \\
\text { penerapan konsep }\end{array}$ \\
\hline $\begin{array}{l}\text { Persamaan matematis } \\
\text { sebaiknya ditulis sendiri, bukan } \\
\text { hasil mengkopi dari internet } \\
\text { seperti pada modul halaman } 69\end{array}$ & $\begin{array}{l}\text { Persamaan matematis } \\
\text { sudah diperbaiki dengan } \\
\text { aplikasi math type oleh } \\
\text { peneliti. }\end{array}$ \\
\hline $\begin{array}{l}\text { Perbaiki soal no. } 5 \text { halaman } 20 \text {. } \\
\text { kenapa tukang cuci mobil } \\
\text { mengangkat batu? }\end{array}$ & $\begin{array}{l}\text { Sudah diganti, penulis } \\
\text { salah ketik harusnya } \\
\text { 'mobil' bukan 'batu' }\end{array}$ \\
\hline $\begin{array}{l}\text { Sampul modul yang } \\
\text { menggambarkan fluida dinamis } \\
\text { diganti gambar sampul yang } \\
\text { menggambarkan fluida statis }\end{array}$ & $\begin{array}{lr}\text { Sudah diganti } & \text { dengan } \\
\text { ekskavator } & \text { yang } \\
\text { menggambarkan } & \text { salah } \\
\text { satu materi fluida statis }\end{array}$ \\
\hline $\begin{array}{l}\text { Lay-out sebaiknya diganti yang } \\
\text { lebih sederhana dan warnanya } \\
\text { di sinergikan dengan sampul } \\
\text { depan }\end{array}$ & $\begin{array}{l}\text { Sudah diganti dan } \\
\text { disesuaikan warnanya } \\
\text { dengan warna dominan } \\
\text { kuning }\end{array}$ \\
\hline $\begin{array}{l}\text { Tambahkan refleksi total } \\
\text { materi pada halaman terakhir } \\
\text { modul agar guru mengetahui }\end{array}$ & $\begin{array}{l}\text { Sudah ditambahkan } \\
\text { kolom 'refleksi diri' } \\
\text { untuk seluruh sub materi }\end{array}$ \\
\hline
\end{tabular}

\begin{tabular}{lc}
\hline \multicolumn{1}{c}{ Sebelum revisi } & \multicolumn{1}{c}{ Setelah revisi } \\
\hline $\begin{array}{l}\text { materi yang sudah/ belum } \\
\text { dipahami siswa }\end{array}$ & di dalam modul. \\
\hline
\end{tabular}

Secara umum perbaikan dilakukan dari segi materi, visualisasi dan kebahasaan. Perbaikan dari segi materi diantaranya memperbaiki peta konsep dan soal-soal evaluasi. Perbaikan dari segi visualisasi diantaranya perbaikan gambar, lay-out, dan equation. Perbaikan dari kebahasaan diantaranya perbaikan redaksi penulisan dan sumber pengambilan gambar. Setelah draf I direvisi dihasilkan draf II berdasarkan masukan dan saran dari validator. Draf II selanjutnya diujicobakan terbatas kepada 10 siswa kelas X-MIPA di SMAN 2 Karanganyar yang terdiri dari siswa dengan kemampuan tinggi, sedang dan rendah yang diambil dari kelas X-MIPA 1, X-MIPA 2, X-MIPA 3 dan X-MIPA 4.

\section{Uji Coba Terbatas}

Tahapan uji coba terbatas ini dilakukan setelah mendapatkan produk yaitu modul cetak pembelajaran fisika berbasis Project Based Learning (PjBL) pada materi fluida statis yang sudah divalidasi oleh validator. Data menunjukkan bahwa hasil uji coba terbatas diperoleh nilai rata-rata seluruhnya 89 dari skor maksimal 108. Apabila skor tersebut dikonversi ke dalam interval 4 maka diperoleh nilai penilaian 3,29 sehingga modul ini termasuk dalam kriteria 'sangat baik'. Nilai tersebut mengartikan bahwa menurut modul pembelajaran fisika berbasis $\mathrm{PjBL}$ pada materi fluida statis yang dikembangkan sangat baik dalam segi isi/ materi, sangat baik dalam segi kebahasaannya dan sangat baik juga dalam segi gambar dan penyajiannya.

\section{Revisi II}

Hasil dari ujicoba terbatas juga berupa saran dan masukan dari siswa yang diperbaiki oleh peneliti, diantaranya perbaikan terhadap hasil cetakan yang kurang jelas, redaksi penulisan yang kurang lengkap dan penambahan konversi satuan. Setelah direvisi, hasil perbaikan kemudian disusun kembali menjadi draft modul III yang diimplementasikan pada uji coba lapangan di 
JURNAL INKUIRI

ISSN: 2252-7893, Vol. 7, No. 1, 2018 (hal 81-92)

http://jurnal.uns.ac.id/inkuiri

kelas X-MIPA.1 SMAN 2 Karanganyar sejumlah 37 siswa.

\section{Uji Coba Lapangan Utama}

Data yang didapatkan dalam ujicoba lapangan dengan penerapan pembelajaran menggunakan modul pembelajaran fisika berbasis $\mathrm{PjBL}$ pada materi fluida statis ini meliputi data hasil penilaian kemampuan sikap, pengetahuan, keterampilan dan data kreativitas belajar siswa. Selain hal tersebut, siswa juga diminta untuk melakukan penilaian terkait penggunaan modul pembelajaran $\mathrm{PjBL}$ dalam mendampingi pemahaman materi tentang fluida statis.

a. Penilaian Kreativitas Belajar Siswa Penilaian kreativitas belajar siswa dilakukan pada 37 siswa kelas X-MIPA.1 SMAN 2 Karanganyar dengan menggunakan pre dan post test dari angket kreativitas belajar berdasarkan penggunaan modul pembelajaran berbasis $\mathrm{PjBL}$ pada penyampaian materi fluida statis.

Aspek penilaian kreativitas belajar siswa terdiri dari sepuluh (10) indikator dengan indikator (1) rasa ingin tahu, mengalami peningkatan nilai ketercapaian dari 72 menjadi 91 dengan nilai gain 0,68 atau berkategori peningkatan yang tinggi. Indikator (2) mengajukan pertanyaan, mengalami peningkatan nilai ketercapaian dari 74 menjadi 90 dengan nilai gain 0,62 atau dalam peningkatan kategori tinggi. Indikator (3) memberikan usulan, mengalami peningkatan ketercapaian dari 75 menjadi 88 dengan nilai gain 0,52 atau dalam kategori sedang. Indikator (4) bebas menyatakan pendapat, mengalami peningkatan nilai ketercapaian dari 83 menjadi 95 dengan nilai gain 0,71 atau dalam kategori peningkatan tinggi. Indikator (5) mempunyai rasa keindahan, mengalami peningkatan nilai dari 67 menjadi 83 dengan nilai gain 0,49 atau dalam kategori sedang. Indikator (6) menonjol dalam bidang seni, belum mengalami peningkatan yang signifikan yakni dari nilai ketercapaian 58 menjadi 66 dengan nilai gain 0,20 atau dalam batas kategori sangat rendah. Hal ini mengindikasikan bahwa penggunaan modul fisika berbasis $\mathrm{PjBL}$ ini belum dapat mendorong siswa untuk mendapatkan penghargaan dalam bidang seni. Indikator (7) mampu melihat permasalahan, mengalami peningkatan ketercapaian dari 75 menjadi 87 dengan nilai gain 0,50 atau dalam kategori sedang. Indikator (8) mempunyai rasa humor, mengalami peningkatan dari 82 menjadi 87 dengan nilai gain 0,29 atau dalam kategori rendah. Indikator (9) memunyai daya imajinasi, mengalami peningkatan nilai ketercapaian dari 67 menjadi 82 dengan nilai gain 0,44 atau dalam kategori sedang. Indikator yang terakhir (10) original dalam gagasan, mengalami peningkatan nilai ketercapaian 68 menjadi 79 dengan nilai gain 0,35 atau dalam kategori sedang. Seluruh data nilai kreativitas belajar siswa ditampilkan dalam Gambar 2.

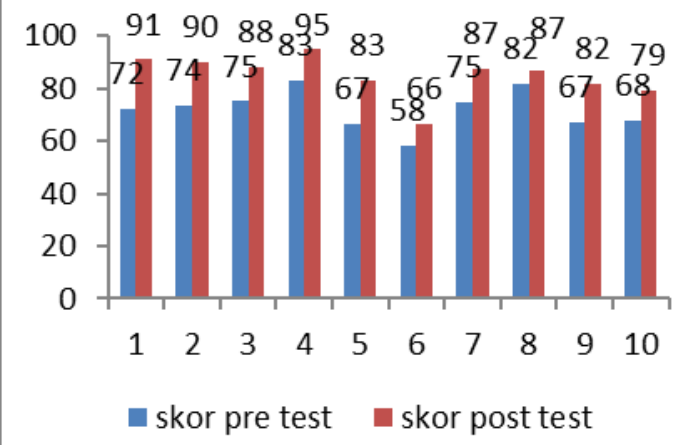

Gambar 2. Grafik Peningkatan Kreativitas Belajar Siswa

Berdasarkan Gambar 2 dapat disimpulkan bahwa pembelajaran menggunakan modul pembelajaran fisika berbasis PjBL pada materi fluida statis dapat meningkatkan kreativitas belajar siswa karena secara keseluruhan aspek kreativitas belajar siswa mempunyai nilai gain 0,46 atau dalam kategori sedang. Hal ini sesuai dengan pernyataan Syaifudin (2011: 43) yaitu berhasil meningkatkan kreativitas belajar ketika hasil perhitungan gain menunjukkan minimal kategori sedang $(0,41<n$-gain $<0,60)$.

Hasil penelitian tersebut ternyata senada dengan hasil penelitian Mukayatun et al (2013) yang menyatakan bahwa setelah adanya pembelajaran berbasis $\mathrm{PjBL}$ terjadi peningkatan rata-rata kemampuan berpikir kreatif dan banyak terjadi respon positif seperti 
siswa merasa senang dan tidak terbebani. Hasil penelitian juga menjawab tantangan yang diberikan dari penelitian Fasko (2001) bahwa kualitas pembelajaran dapat ditingkatkan melalui peningkatan kreativitas dalam pembelajaran. Aktivitas yang dihasilkan dalam pembelajaran PjBL juga dapat meningkatkan kreativitas belajar seperti yang diungkapkan dalam penelitian Yang \& Guo (2013).

\section{b. Hasil Belajar Aspek Sikap Ilmiah}

Penilaian komponen sikap ilmiah dilakukan selama pelaksanaan pembelajaran menggunakan modul berbasis $\mathrm{PjBL}$ yang pengamatannya dibantu oleh observer I, observer II dan observer III dalam penilaiannya. Aspek yang dinilai adalah rasa ingin tahu, jujur, disiplin, kreatif dan kerja keras.

Hasil penilaian memperlihatkan bahwa sikap ilmiah siswa dalam pembelajaran menggunakan modul berbasis $\mathrm{PjBL}$ ini mulai membudaya. Sikap yang dimaksud berarti adalah rasa ingin tahu yang mulai berkembang baik, kejujuran yang terlihat berkembang baik, kedisiplinan belajar yang mulai berkembang baik, ide kreatif dalam pembelajaran yang mulai berkembang baik dan kerja keras yang ditunjukkan dalam proses pembelajaran juga mulai berkembang baik menuju pembiasaan yang membudaya. Hasil ini sejalan dengan penelitian Mukayatun et al (2013) bahwa peningkatan kreativitas dapat meningkatkan aspek sikap belajar siswa. Penelitian Yalcin et al (2009) juga menyebutkan hal senada, bahwa dengan pembelajaran PjBL dapat mennghasilkan sikap belajar yang lebih baik karena dapat menggairahkan siswa dalam belajar.

c. Hasil Belajar Aspek Pengetahuan

Penilaian aspek pengetahuan siswa dilakukan setelah adanya forum presentasi oleh masing masing kelompok mengenai proyeknya masing-masing. Setelah tanya jawab selesai dan adanya penguatan dari guru setelah itu dilaksanakan penugasan untuk mengerjakan soal evaluasi utuk masing-masing kegiatan belajar (KB).

Hasil penelitian menjelaskan bahwa Kegiatan Belajar (KB).1 tentang hukum Pascal mempunyai nilai rata-rata 73 , KB.2 tentang hukum Archimedes dengan nilai rata-rata 76, KB.3 tentang Kapilaritas dengan nilai rata-rata 77 dan KB.4 tentang Viskositas dengan nilai rata-rata 88. Data penilaian tersebut secara keseluruhan dirata-rata dan disimpulkan bahwa bahwa 25 siswa dinyatakan Lulus dan 11 siswa harus melalui proses remediasi. Secara keseluruhan hasil belajar menggunakan modul berbasis PjBL ini dinyatakan berhasil karena nilai rata-rata siswa (78) sudah melebihi angka kriteria ketuntasan minimal $(\mathrm{KKM}=75)$. Hasil penelitian ini senada dengan penelitian Yang \& Guo (2013) bahwa dengan menggunakan pembelajaran berbasis PjBL dapat meningkatkan kualitas dan hasil belajar siswa khususnya dalam aspek pengetahuan.

\section{d. Hasil Belajar Aspek Keterampilan}

Penilaian keterampilan (aspek psikomotorik) siswa di dalam penelitian ini berdasarkan lembar observasi tugas proyek pada setiap kelompok. Seluruh siswa dibagi menjadi 6 kelompok dengan masing-masing proyek sesuai dengan pembagiannya masingmasing, yaitu kelompok (1) dan (2) tentang proyek robot hidrolik, kelompok (2) dan (3) tentang proyek balon udara, dan kelompok (4) dan (5) tentang proyek lilin aromatherapi.

Pembagian kelompok terdiri dari 6 kelompok dengan kriteria penilaian terdiri dari 3 aspek penilaian yang terdiri dari aspek (1) perencanaan proyek, (2) proses pembuatan, dan (3) hasil produk dan pelaporan proyek. Tiga aspek penilaian tersebut dijabarkan masing-masing menjadi 3 deskriptor yang disusun dalam lembar observasi tugas proyek. Secara keseluruhan aspek keterampilan siswa dikategorikan 'baik' dengan rata-rata penilaian 3,1. Rincian penilaiannya adalah kelompok 1 dengan nilai rata-rata penilaian keterampilan 2,4 (cukup baik), kelompok 2 mendapatkan skor penilaian rata-rata 3,7 (sangat baik), kelompok 3 mendapatkan skor penilaian ratarata 3,4 (sangat baik), kelompok 4 dengan skor penilaian rata-rata 3,0 (baik), kelompok 5 dengan skor penilaian rata-rata 2,7 (baik), dan kelompok 6 dengan skor penilaian rata-rata 3,3 (sangat baik). Nilai-nilai ini mengartikan bahwa dengan menggunakan bantuan modul 
berbasis PjBL dapat membuat siswa terampil dalam mengaplikasikan konsep pelajaran yang dipahaminya.

Hasil pembelajaran aspek keterampilan pada penelitian ini sejalan dengan manfaat PjBL yang diungkapkan Yalcin et al (2009) yang dapat membuat pembelajaran lebih bersemangat dan bermotivasi tinggi sehingga keterampilan siswa juga menjadi lebih baik. Hasil ini juga menjawab tantangan hasil penelitian Mukayatun et al (2013) yang dengan pembelajaran PjBL-nya belum dapat mempengaruhi aspek psikomotorik siswa, akan tetapi pada penelitian pengembangan modul pembelajaran berbasis $\mathrm{PjBL}$ yang dilakukan peneliti membuat aspek keterampilan siswa menjadi baik.

\section{e. Penilaian Produk oleh Siswa}

Modul pembelajaran berbasis $\mathrm{PjBL}$ ini setelah pembelajaran selesai dilakukan penilaian oleh siswa mengenai komponen isi/ materi, bahasa dan tampilan/ gambar dalam bentuk angket penilaian produk yang terdiri dari 27 butir deskriptor. Komponen isi/ materi terdiri dari 11 butir, komponen kebahasaan 3 butir, dan komponen tampilan/ gambar terdiri dari 13 butir.

Hasil penilaian 37 siswa di kelas XMIPA 1 SMAN 2 Karanganyar tersebut mengkategorikan modul pembelajaran berbasis PjBL ini dalam kriteria 'Sangat Baik'. Rincian penilaian modul oleh siswa tersebut yaitu 3,63 pada komponen isi/ materi yang tersaji dalam butir angket nomor 1-11, kemudian nilai 3,43 untuk skor kebahasaan yang tersaji dalam butir angket nomor 12-14 dan nilai 3,42 untuk skor penilaian tampilan/ gambar pada butir angket nomor 15-27. Nilai rata-rata keseluruhan modul adalah 3,51 (sangat baik) yang mengartikan bahwa modul pembelajaran fisika berbasis PjBL mempunyai kualitas yang sangat baik dari segi materi, bahasa dan tampilan/ gambarnya. Penilaian tersebut mengartikan bahwa modul sangat baik dipakai dalam pembelajaran sehingga dapat menjadi alternatif pendekatan dalam pemecahan permasalahan siswa seperti yang diungkapkan dalam penelitian Kiong et al (2011).

\section{Penyempurnaan (Revisi III)}

Hasil uji lapangan dan penilaian produk dari siswa menunjukkan bahwa isi/ materi sudah baik, bahasa di dalam modul juga sudah baik dan tampilan/ gambar sudah sangat baik sehingga tahap selanjutnya adalah menyempurnakan modul dari saran beberapa siswa dalam uji lapangan utama. Saran tambahan dalam revisi III ini hanya sedikit, diantaranya hanya memperjelas gambar dan penambahan kata mutiara. Perbaikan yang lebih sedikit daripada revisi sebelumnya, hal ini menunjukkan bahwa modul yang dikembangkan sudah lebih baik dari sebelumnya dan siap untuk disebarkan ke sekolah-sekolah lain.

\section{Tahap Disseminate}

Pada tahap penyebaran, modul fisika berbasis $\mathrm{PjBL}$ pada materi fluida statis ini disebarkan di 5 sekolah di kabupaten Karanganyar. Penyebaran dilakukan di SMAN 1 Karanganyar, SMAN 2 Karanganyar, SMAN Karangpandan, SMAN Jumapolo, dan SMAN Mojogedang. Setelah diberikan modul fisika berbasis PjBL beserta RPP pada materi fluida statis ini kemudian guru-guru tersebut melakukan penilaian yang disajikan dalam angket respon dan keterbacaan modul yang terdiri dari 5 pertanyaan.

Hasil penilaian memperlihatkan secara rinci data penilaian produk oleh guru dalam tahap penyebaran ini. Responden 1 adalah guru fisika yang berasal dari SMAN 1 Karanganyar, memberikan nilai 3,8 atau dengan kategori sangat baik. Responden 2 berasal dari SMAN 2 Karanganyar memberikan nilai 3,6 (sangat baik), Responden 3 berasal dari SMAN Karangpandan yang menilai 3,6 (sangat baik). Responden 4 adalah guru fisika yang berasal dari SMAN Jumapolo yang memberikan nilai 4,0 pada modul (sangat baik), dan responden 5 adalah guru fisika yang berasal dari SMAN Mojogedang yang memberikan penilaian 3,8 (sangat baik) pada modul. Jadi, secara keseluruhan pengembangan modul pembelajaran fisika berbasis yang berbasis PjBL pada materi fluida statis ini mempunyai nilai rata-rata seluruhnya 3,8 atau dalam kategori 'sangat baik'. Nilai ini membuktikan 
bahwa menurut guru fisika di 5 sekolah tersebut, modul fisika berbasis PjBL yang dikembangkan peneliti mempunyai kualitas sangat bagus dari segi materi, bahasa dan tampilan/ gambar sehingga sangat layak dipergunakan dalam pembelajaran fisika di SMA/MA. Hal tersebut senada dengan hasil penelitian Sampurno (2009) bahwa pembuatan media pembelajaran yang baik sangat perlu dilakukan demi meningkatkan kualitas pembelajaran.

\section{Kesimpulan dan Rekomendasi}

\section{Kesimpulan}

Kesimpulan dari hasil penelitian pengembangan modul pembelajaran fisika berbasis PjBL pada materi fluida statis untuk kelas $\mathrm{X}$ SMA/MA yang telah dilakukan adalah:

1. Karakteristik khusus pengembangan modul pembelajaran berbasis $\mathrm{PjBL}$ yang dikembangkan peneliti memiliki enam sintaks pembelajaran $\mathrm{PjBL}$ yaitu penentuan pertanyaan mendasar, perancangan proyek, penyususnan jadwal, pengawasan kemajuan proyek, pengujian hasil, dan pengevaluasian pengalaman yang diintegrasikan ke dalam rubrik di dalam modul.

2. Modul fisika berbasis PjBL yang dikembangkan memenuhi kriteria layak pada aspek kelayakan isi dan penyajian, kelayakan bahasa, kelayakan aspek pembelajaran PjBL, dan kelayakan kegrafikan dengan nilai rata-rata 3,8 atau dalam kategori 'sangat baik'.

3. Pembelajaran menggunakan modul pembelajaran fisika berbasis $\mathrm{PjBL}$ pada materi fluida statis dapat meningkatkan kreativitas belajar siswa dengan nilai gain 0,46 atau dalam kategori sedang.

\section{Rekomendasi}

Dalam penggunaan modul pembelajaran berbasis $\mathrm{PjBL}$ perlu diperhatikan beberapa hal diantaranya (1) Kepada guru mata pelajaran Fisika untuk lebih variatif dalam penggunaan metode pembelajaran yang sesuai dengan materi yang akan disampaikan. Serta perlu dikembangkan modul pembelajaran yang dapat digunakan sebagai panduan siswa dalam belajar mandiri sebagai salah satu sarana pembelajaran. (2) Perlu adanya persiapan yang baik dalam pembelajaran menggunakan modul pembelajaran fisika berbasis $\mathrm{PjBL}$ agar proses pembelajaran dapat berlangsung dengan baik sesuai dengan RPP yang telah dipersiapkan. (3) Hasil penelitian ini dapat digunakan sebagai acuan untuk mengembangkan penelitian sejenis, terutama penelitian pengembangan modul dalam pembelajaran fisika. Peneliti dapat mengembangkan modul dengan pendekatan pembelajaran dan materi yang berbeda.

\section{Daftar Pustaka}

De graff, J \& Lawrence, K., A. (2002). Creativity at Work: Developing the Right Practices to Make Innovation Happen. San Francisco: Jossey-Bass Company

Djuandi. (Ed). (2014). Instrumen Penilaian Buku Teks. Jakarta: bsnp-indonesia.org

Depdiknas. (2008). Teknik Penyusunan Modul. Jakarta: Depdiknas

Fasko, D. (2001). Education and Creativity. Creativity Reasearch Journal, 3 (13), 317327.

Grant, M, M \& Tamim, S, R. (2013). Definition and Uses: Case Study of Teachers Implementing Project-based Learning. Interdiciplinary Journal of Problem-based Learning, 7 (2), 72-101.

Haryanto. (2013). Menyusun Modul Bahan Ajar untuk Persiapan Guru dalam Mengajar. Yogyakarta: Gava Media.

Kiong, T.T. et al. (2011). Procedia - Social and Behavioral Sciences, The Development And Evaluation Of The Qualitis Of Buzan Mid Mapping Module. Malaysia: Universiti Tun Hussein.

Meltzer, D.E. (2001). The Relationship between Mathematics Preparation and Conceptual Learning Gains in Physics: a Possible "Hidden Variable" in Diagnostic Pretest Scores. United States: Lowa State University. 
Menteri Pendidikan dan Kebudayaan. (2014). Permendikbud RI No.59 Tahun 2013 tentang Kurikulum 2013 SMA/ MA. Jakarta : Kemendikbud.

Mukayatun et al.(2013). Pembelajaran Biologi dengan Pendekatan CTL dengan Teknik Network Tree dan Spider Concept Map Ditinjau dari Kreativitas dan Gaya Berpikir Peserta Didik. Jurnal Inkuiri FKIP UNS, 1 (2), 14-24.

Mukhayyarotin, N . (2013). Pengembangan Modul Fisika Berbasis Problem Based Learning pada Materi Fluida untuk Siswa Cerdas Istimewa-Berbakat Istimewa (CIBI). Tesis. Universitas Sebelas Maret Surakarta.

Novitayani, L. (2014). Pengembangan Modul Fisika Berbasis Somatic, Auditory, Visual, Intelectual (SAVI) untuk Meningkatkan Kreativitas Belajar Siswa. Tesis. Universitas Sebelas Maret Surakarta.

Puspendik. (2013). Laporan Hasil Ujian Nasional Tahun Pelajaran 2012/2013. Jakarta: Kementrian Pendidikan dan Kebudayaan.

Puspendik. (2014). Laporan Hasil Ujian Nasional Tahun Pelajaran 2013/2014. Jakarta: Kementrian Pendidikan dan Kebudayaan.

Sampurno, A. (2009) Penerapan Metode Belajar Akif dalam Pembelajaran Berbasis Proyek untuk Meningkatkan Hasil Belajar. Tesis. Universitas Negeri Yogyakarta.

Sugiyono. (2012). Metode Penelitian Kuantitatif, kualitatif dan $R \& D$. Bandung: Penerbit Alfabeta.

Susilana, R \& Riyana, C. (2007). Media Pembelajaran. Bandung: CV Wacana Prima.

Thiagarajan, dkk. (1974). Instructional Development for Training Teacher of Exceptional children. Bloomington Indiana: Indiana University.

Trianto. (2010). Mendesain Pembelajaran Kontekstual di Kelas. Surabaya: Cerdas Pustaka Publisher.

Yalcin, S., A., Turgut, U \& Buyukkasap, E. (2009). The Effect of Project Based Learning on Science Undergraduates' Learning of Electricity, Attitude towards Physics and Scientific Process Skills. International Online Journal of Education Sciences. 1 (1) $81-105$.
Yang, Y \& Guo, Y. (2013). Project Based Learning: an Effective Approach to Link Teacher Professional Development and Students Learning. Journal of Educational Technology Development and Exchange, 5 (2), 41-45. 
JURNAL INKUIRI

ISSN: 2252-7893, Vol. 7, No. 1, 2018 (hal 81-92)

http://jurnal.uns.ac.id/inkuiri 